\title{
ANALISIS FAKTOR-FAKOR YANG MEMPENGARUHI KECEMASAN PASIEN CA MAMAE DENGAN TINDAKAN KEMOTERAPI
}

\author{
Danang Tri Yudono ${ }^{1}$ \\ ${ }^{1}$ Program Studi S1 Keperawatan Universitas Harapan Bangsa \\ danangty_85@yahoo.com
}

\begin{abstract}
ABSTRAK
Sekitar 39.620 wanita meninggal dunia setiap tahunnya karena kanker payudara (Depkes, 2013) di Indonesia. Salah satu penatalaksanaan medis pada pasien kanker yaitu dengan tindakan kemoterapi, beberapa efek samping dari kemoterapi yaitu berupa efek fisi seperti gangguan pencernaan, gangguan hormon, dan efek psikologis yang berupa kecemasan. Penelitian ini bertujuan untuk mengetahui factor-faktor mempengaruhi tingkat kecemasan pada pasien Ca Mamae dengan tindakan kemoterapi. Penelitian ini menggunakan desain deskriptif korelasional dengan pendekatan cross sectional. Alat yang digunakan dalam penelitian ini adalah kuesioner yang diadaptasi dari instrumen ZSAS (Zung Scale Anciety Score) untuk mengukur kecemasan pada pasien Ca Mamae dengan kemoterapi . Penelitian ini menggunakan sampel sebanyak 44 responden, dengan tehnik pengambilan sampel menggunakan purposife sampling, dengan kriteria inlkusi dan ekslusi. Variable yang diteliti meliputi, usia, pekerjaan, pendidikan, stadium kanker, dan riwayat kemoterapi, dan tingkat kecemasan. Metode analisis data menggunakan univariat dengan cros tabulasi dan bivariate menggunakan uji Chi Quare. Hasil penelitian ini diperoleh factor usia, pekerjaan, pendidikan, riwayat kemoterapi dan stadium kanker merupakan salah satu penyebab kecemasan.dari hasil Chi Square usia $p=0.45(p>0.5)$, pendidikan $p=95(p>0.05)$, pekerjaan $p=0.85$ ( $p>0.05)$, stadium kanker $p=0.000$ ( $p<0.05)$, frekwensi kemoterapi $p=0.47$ $(p>0.05)$ hal ini menunjukan bahwa factor yang paling berpengaruh terhadap kecemasan yaitu pada stadium kanker.

Kesimpulan dan saran : pada penelitian disimpulkan bahwa factor stadium kanker merupakan factor utama yang paling mempengaruhi tingkat kecemasan. Saran dalam penelitian ini kepada rumah sakit terkait diharapkan dapat memberikan edukasi dan implementasi keperawatan terhadap pasien kemoterapi.
\end{abstract}

Kata kunci: usia, pekerjaan, pendidikan, stadium kanker, frekwensi kemoterapi, kecemasan, kemoterapi.

\section{ABSTRACT}

About 39,620 women die each year from breast cancer (MOH, 2013) in Indonesia. One medical treatment in cancer patients is by chemotherapy, some side effects of chemotherapy are fission effects such as digestive disorders, hormonal disorders, and psychological effects in the form of anxiety. This study aims to determine what factors influence the level of anxiety in Ca Mamae patients with chemotherapy. This study used a descriptive correlational design with a cross sectional approach. The tool used in this study is a questionnaire adapted from the ZSAS (Zung Scale Anciety Score) instrument to measure anxiety in Ca Mamae patients with chemotherapy. This study aims us sample to 44 responden, with us tehnice to purposive sampling us criteria inclusi and ekslusi. Variable us study is factor-factor with anciety for in Ca Mamae. Metode analis data for study us univariate with cros tabulation and bivariate us Chi Quare.The results of this study obtained factors of age, work, education, history of chemotherapy and stage of cancer is one of the causes of anxiety. From Chi Square results, age $p=0.45(p>0.5)$, education $p=95(p>0.05)$, work $p=0.85(p>0.05)$, cancer stage $p=0.000(p<0.05)$, the frequency of chemotherapy $p=0.47$ ( $p>0.05)$, indicating that the most influential factor in anxiety is at the 
stage of cancer.

Conclusion research there is stadium is the main factor that affects the level of anxiety. patients with chemomotherapy.

Keywords: age, occupation, education, stage of cancer, frequency of chemotherapy, anxiety, chemotherapy.

\section{PENDAHULUAN}

Sekitar 39.620 wanita meninggal dunia setiap tahunnya karena kanker payudara (Depkes, 2013) di Indonesia, kanker payudara menempati urutan ke dua setelah kanker leher rahim. Kejadian kanker payudara di Indonesia sebesar $11 \%$ dari seluruh kejadian kanker . Sekitar 70 persen pasien kanker payudara datang ke rumah sakit berada pada kondisi stadium lanjut.

Upaya tindakan medis untuk pengobatan kanker yaitu pembedahan, radioterapi, dan kemoterapi. Kemoterapi merupakan terapi sistemik, yang berarti obat menyebar keseluruh tubuh dan dapat mencapai sel kanker yang telah menyebar jauh atau metastase ketempat lain (Rasjidi, 2012). Kemoterapi dapat mempengaruhi kesehatan sel begitu juga sel kanker, yang menyebabkan efek samping yang umumnya pada pengobatan. Efek samping pada klien dengan kemoterapi secara fisik yaitu dapat merasakan mual dan muntah, gangguan pencernaan, diare, kerusakan kulit, kebotakan, depresi sum-sum tulang belakang yang mengakibatkan penurunan produksi selsel darah merah sehingga pasien bisa mengalami anemia dan penurunan sistem imun tuhun, sedangkan secara psikologis klien merasakan takut, cemas sampai dengan kepanikan. (Zsmelter, 2010).

Pada pasien yang baru pertama kali menjalani kemoterapi seringkali pasien terlalu tinggi menilai bahaya dan terlalu rendah menilai kemampuan diri. Pasien akan mengalami ketakutan atau kecemasan terhadap tindakan dan efek samping kemoterapi tersebut. (Desen, 2011). Hasil penelitian tentang kecemasan pada pasien kanker payudara yang menjalani kemoterapi di RS Sultan Agung Semarang yang dilakukan oleh Uliana (2015), menunjukan sebanyak $53,3 \%$ responden mengalami kecemasan berat, 52,3\% mengalami kecemasan sedang, 18,2\% mengalami kecemasan ringan, dimana hasil penelitian ini menunjukan sebagian besar pasien kanker payudara yang 
menjalani kemoterapi mengalami cemas kategori berat.

Kecemasan yang ditimbulkan pada pasien Ca Mamae dengan tindakan kemoterapi banyak dipengaruhi oleh beberapa factor, antara lain, berupa usia, pengalaman, pendidikan, riwayat kemoterapi, stadium kanker dan beberapa faktor yang lain. Kecemasan yang dialami oleh beberapa pasien kemoterapi akan menimbulkan respon yang tidak nyaman dalam proses pengobatan sehingga akan mempenyaruhi penyembuhan kondisi pasien. Kondisi seperti ini harus segera di tangani oleh petugas perawat untuk mengetahui apa saja faktor yang mempengaruhi kecemasan pada pasien kemoterapi, sehingga dapat dilakukan penatalaksanaan secara tepat dan komprehensif (Isaacs, 2013).

Dari data tersebut diatas maka peneliti tertarik untuk mengambil judul penelitian tentang analisis faktor faktor yang mempengaruhi kecemasan pada pasien Ca Mamae dengan tindakan Kemoterapi di RS dadi Keluarga Banyumas.

\section{METODE PENELITIAN}

Penelitian ini menggunakan desain deskriptif korelasional dengan pendekatan cross sectional. Alat yang digunakan dalam penelitian ini adalah kuesioner ZSAS untuk mengukur kecemasan dan lembar observasi untuk mengetahui faktor-faktor kecemasan. Kuesioner ZSAS merupakan alat ukur untuk mengukur tingkat kecemasan pada beberapa responden, kuesioner ini sudah banyak digunakan oleh beberapa peneliti. Uji validitas dan realibilitas pada kuesioner ZSAS mendapatkan hasil nilai validitas dan realibilitas yang tinggi.

Pengambilan sampel menggunakan teknik purposive sampling. Responden adalah pasien yang memiliki karakteristik sebagai berikut; pasien $\mathrm{Ca}$ Mamae dengan tindakan kemoterapi 16, pasien kondisi komposmetis, pasien dengan kecemasan. Pasien dikeluarkan jika kondisi pasien mengalami penurunan kesadaran pada saat dilakukan penelitian. Responden penelitian terdiri dari 44 responden pasien Ca Mamae dengan Kemoterapi . Penentuan besar sampel dalam penelitian ini dengan menggunakan rumus besar sampel menurut (Sugiono 2010). Penelitian ini diambil dalam 
rentang waktu bulan april - Agustus 2018. Variabel dalam peelitian ini meliputi variable bebas yaitu factor yang mempengaruhi kecemasan dan variable terikat yaitu pasien Ca Mamae dengan kemoterapi.

Data dianalisis statistik yang digunakan menggunakan analisa univariat untuk mengetahui karakteristik responden dan faktor yang mempengaruhi kecemasan, analisa bivariate menggunakan Chi Square untuk menghubungkan antara faktorfaktor kecemasan

\section{HASIL DAN PEMBAHASAN}

$\mathrm{Bab}$ ini menyajikan, menganalisis dan menafsirkan temuan berdasarkan masalah-masalah khusus penelitian.
Berdasarkan tabel 1.1 dari hasil penelitian menunjukan bahwa karakteristik responden yang menderita Ca Mamae berdasarkan umur jumlah terbanyak dengan kategori lansia berjumlah 36 orang $(81.8 \%)$, berdasarkan pendidikan 19 orang (43.3\%) rata-rata responden berpendidikan SMP, berdasarkan pekerjaan terdapat 22 orang (50\%) sebagian besar dari responden bekerja sebagai ibu rumah tangga, , berdasarkan stadium kanker terdapat 21 orang (47.7\%) hampir sebagian besar dari responden mengalami stadium kanker derajat 3, berdasarkan Frekwensi kemoterapi sebanyak 13 orang (29.5\%) dengan riwayat kemoterapi ke 5.

Table 1.1 Distribusi pasien $\mathrm{Ca}$ Mamae berdasarkan umur, pendidikan, pekerjaan, stadium kanker, frekwensi kemoterapi di rumah sakit Dadi Keluarga Banyumas

\begin{tabular}{|c|c|c|}
\hline \multirow{2}{*}{ Variable } & \multicolumn{2}{|c|}{ Responden } \\
\hline & $\mathrm{N}$ & $\%$ \\
\hline \multicolumn{3}{|l|}{ Usia } \\
\hline Dewasa akhir & 8 & 18.2 \\
\hline Lansia & 36 & 81.8 \\
\hline Jumlah & 44 & $100 \%$ \\
\hline \multicolumn{3}{|l|}{ Pendidikan } \\
\hline $\mathrm{SD}$ & 13 & 29.5 \\
\hline SMP & 19 & 43.1 \\
\hline SMU & 10 & 22.7 \\
\hline PT & 2 & 4.5 \\
\hline
\end{tabular}




\begin{tabular}{lcc} 
Jumlah & 44 & $100 \%$ \\
\hline Pekerjaan & 22 & 50 \\
IRT & 12 & 27.2 \\
Petani & 2 & 4.5 \\
PNS/Pensiun & 8 & 18.1 \\
Swasata & 44 & $100 \%$ \\
Jumlah & & \\
\hline Stadium Kanker & 19 & 43.1 \\
Stadium 2 & 21 & 47.2 \\
Stadium 3 & 4 & 9 \\
Stadium 4 & 44 & $100 \%$ \\
Jumlah & & \\
Frekwensi Kemoterapi & 3 & 6.8 \\
Kemoterapi 1 & 4 & 9 \\
Kemoterapi 2 & 5 & 11.3 \\
Kemoterapi 3 & 12 & 27.2 \\
Kemoterapi 4 & 13 & 29.5 \\
Kemoterapi 5 & 7 & 15.9 \\
Kemoterapi 6 & 44 & $100 \%$ \\
Jumlah & & \\
\hline
\end{tabular}

Berdasarkan hasil penelitian didapatkan usia responden kanker payudara pada paling banyak di derita pada usia lansia. Hal ini sesuai dengan data dari WHO (World Health Organitation) menunjukan bahwa $76 \%$ angka kejadian kanker payudara pada wanita diatas 50 tahun (Abidin, 2014).

Hal ini sesuai dengan pendapat Tjipto dalam penelitian Surbakti (2013), bahwa ada kecenderungan meningkatnya penyakit kanker payudara sejalan dengan bertambahnya usia. Pada masa usia post menoupous hormone progestreron tidak dapat dihasilkan dalam jumlah yang cukup, sehingga jumlah hormone estrogen tidak dapat dikendalikan.

Berdasarkan hasil penelitian dilihat dari tingkat pendidikan pasien kanker payudara yang menjalani program kemoterapi di Rumah Sakit Dadi Keluarga Banyumas sebagian besar berpendidikan SD dan SMP. Menurut Notoatmodjo dalam penelitian Widianty (2012), menunjukan bahwa semakin tinggi tingkat pendidikan maka semakin tinggi tingkat pengetahuan seseorang. Pada hasil penelitian tingkat pendidikan responden sebagian besar tingkat pendidikan SMP, sehingga pengetahuan responden terkait 
Viva Medika: Jurnal Kesehatan, Kebidanan, dan Keperawatan, 11 (02), Maret 2019

Danang Tri Yudono (Analisis Faktor-Fakor Yang Mempengaruhi Kecemasan Pasien Ca Mamae Dengan Tindakan Kemoterapi )

bagaimana pencegahan penyakit kanker payudara masih sedikit.

Hasil penelitian ini menunjukan bahwa pekerjaan responden sebagian besar yaitu IRT dan petani. Dari data tersebut maka dapat dikaitkan dengan akses informasi dan tingkat kesadaran responden untuk memperoleh sumber informasi kaitannya dengan penyakit kanker payudara mengenai pencegahan, gaya hidup dan faktor-faktor yang menyebabkan terjadinya kanker payudara sangatlah sedikit, dikarenakan mereka sibuk dengan pekerjaan seperti bertani dan menjadi ibu rumah tangga untuk mengurus pekerjaan di rumah. Hal itu sesuai dengan hasil penelitian Rahmawati (2014), menyatakan bahwa responden sibuk dengan pekerjaan sehingga kurang memperhatikan dan mendapatkan informasi mengenai penyakit kanker payudara.

Kesibukan dalam bekerja sebagai ibu rumah tangga dan petani menyebabkan responden tidak memperhatikan terkait dengan pencegahan penyakit payu dara. Peneliti berasumsi bahwa salah satu pemicu terjadinya kanker payudara dikarenakan bahwa minimnya sumber informasi dan kurang memperhatikan terkait dengan kesehatan terhadap penyakit kanker payudara.

Frekwensi kemoterapi pada penelitian ini menunjukan data bahwa sebagian besar responden melakukan kemoterapi ke lima dank e empat. Hal ini berkaitan dengan penelitian Astari (2015), yang menyatakan bahwa pengalaman pasien yang baru pertama kali menjalani pengobatan merupakan pengalaman berharga untuk pengobatan berikutnya. Pengobatan kemoterapi yang terdiri dari beberapa siklus merupakan pengobatan dalam jangka panjang, apabila dalam pengalaman pertama dalam menjalani pengobatan kemoterapi tidak mengenakan terhadap efek samping kemoterapi maka akan mempengaruhi tingkat kecemasan pada pengobatan kemoterapi berikutnya.

Sesuai penelitian dari Hastuti, (2015), menyatakan bahwa kemoterapi merupakan zat kimia, tidak hanya membunuh sel kanker pada payudara tetapi juga sel yang ada diseluruh tubuh, sehingga menyebabkan efek samping yang tidak menyenangkan sseperti, mual dan muntah, menurunnya nafsu 
Viva Medika: Jurnal Kesehatan, Kebidanan, dan Keperawatan, 11 (02), Maret 2019

Danang Tri Yudono (Analisis Faktor-Fakor Yang Mempengaruhi Kecemasan Pasien Ca Mamae Dengan Tindakan Kemoterapi )

makan, nyeri pada seluruh tubuh dan sebagainya.

Peneliti berasumsi bahwa kemoterapi pertama pada lebih banyak pada kelompok intervensi dibandingkan kelompok kontrol akan tetapi tidak mempengaruhi tingkat kecemasan pada responden. Efek samping kemoterapi yang tidak mengenakan yang mempengaruhi kecemasan responden untuk kemoterapi selanjutnya.

Stadium penyakit kanker payudara pada penelitian ini menunjukan data bahwa sebagian besar responden dengan stadium tiga $\mathrm{Hal}$ ini berkaitan dengan penelitian Purwanti (2014) yang menyatakan bahwa stadium penyakit kanker sangat berkaitan dengan efek komplikasi yang ditimbulkan dari penyakit tersebut, efek komplikasi dari suatu penyakit akan membuat pasien merasakan keluhan seperti nyeri pada seluruh tubuh dan merasa tidak nyaman. Peneliti berasumsi bahwa semakin tinggi stadium dari penyakit kanker payudara maka akan memperbanyak keluhan yang dialami oleh pasien dan menimbulkan kecemasan yang meningkat, sebaliknya semakin rendah stadium dari penyakit kanker payudara maka akan sedikit komplikasi yang dialami oleh pasien sehingga kecemasan akan menurun (Praptini, 2012).

Berdasarkan analisis hubungan factor-faktor yang mempengaruhi kecemasan pada pasien $\mathrm{Ca}$ Mamae dengan tindakan kemoterapi di RS Dadi Keluarga

Banyumas

Table 1.2 Analisis hubungan kecemasan dengan usia, pekerjan, pendidikan, stadium kanker, dan riwayat kemoterapi.

\begin{tabular}{lllll}
\hline $\begin{array}{l}\text { Karakteristik } \\
\text { Demografi }\end{array}$ & $\begin{array}{c}\text { Cemas ringan } \\
\mathrm{N}(\%)\end{array}$ & $\begin{array}{c}\text { Kecemasan } \\
\text { Cemas sedang } \\
\mathrm{N}(\%)\end{array}$ & $\begin{array}{c}\text { Cemas berat } \\
\mathrm{N}(\%)\end{array}$ & p value \\
\hline Usia & $6(13.6)$ & $2(4.5)$ & $0(0)$ & \\
$\begin{array}{l}\text { Dewasa akhir } \\
\text { Lansia }\end{array}$ & $17(38.6)$ & $16(36.3)$ & $3(6.8)$ & 0.48 \\
\hline Pekerjaan & $11(25)$ & $10(22.7)$ & $1(2.2)$ & \\
IRT & $10(22.7)$ & $4(9.0)$ & $2(4.4)$ & 0.95 \\
Petani & $9(20.4)$ & $3(6.6)$ & $0(0)$ & \\
Wiraswasta & $1(2,2)$ & $1(2.2)$ & $0(0)$ & \\
PNS & & $6(13.6)$ & $1(2.2)$ & \\
Pendidikan & $8(18,1)$ & &
\end{tabular}


Viva Medika: Jurnal Kesehatan, Kebidanan, dan Keperawatan, 11 (02), Maret 2019

Danang Tri Yudono (Analisis Faktor-Fakor Yang Mempengaruhi Kecemasan Pasien Ca Mamae Dengan Tindakan Kemoterapi )

\begin{tabular}{lllll} 
SMP & $8(18.1)$ & $13(29.5)$ & $3(6.6)$ & \\
SMU & $6(13.6)$ & $4(9.0)$ & $0(0)$ & \\
PT & $1(2.2)$ & $1(2.2)$ & $0(0)$ & 0.85 \\
\hline Stadium Kanker & & & & \\
Stadium 2 & $17(38.6)$ & $2(4.4)$ & $0(0)$ & \\
Stadium 3 & $6(13.5)$ & $15(34.0)$ & $0(0)$ & \\
Stadium 4 & $0(0)$ & $0(0)$ & $3(6.6)$ & 0.00 \\
\hline
\end{tabular}

Frekwensi Kemoterapi

Kemoterapi $1 \quad 2(4.4) \quad 1(2.2) \quad 0(0)$

Kemoterapi 2 2(4.4) $1(2.2) \quad 1(2.2)$

Kemoterapi $3 \quad 2(4.4) \quad 3(6.6) \quad 0(0)$

Kemoterapi $4 \quad 6(13.6) \quad 6(13.6) \quad 0(0)$

Kemoterapi $5 \quad 7(15.8) \quad 5(11.3) \quad 1(2.2)$

\begin{tabular}{llllll} 
Kemoterapi 6 & $4(9.0)$ & $2(2.2)$ & $1(0)$ & 0.47 & \\
\hline & & & diperoleh pada pendidikan & SMP.
\end{tabular}

Berdasarkan tabel 4.2 hasil

analisis hubungan tingkat kecemasan dengan usia, pekerjaan, pendidikan, stadium kanker dan riwayat kemoterapi menunjukan bahwa, pada tingkat usia dewasa akhir menunjukan bahwa paling banyak 6 responden mengalami cemas ringan, sedangkan pada usia lansia sebanyak 17 responden mengalami cemas ringan. Pada jenis pekerjaan menunjukan bahwa cemas ringan dan sedang diperoleh baling banyak pada pekerja ibu RT sebanyak 11 dan 10 responden, sedangkan cemas berat didapatkan pada pekerjaa petani sebnyak 2responden. Pada tingkat pendidikan paling cemas ringan paling banyak didapatkan pada tingkat pendidikan SD dan SMP, sedangkan pada cemas sedang
Pada tingkat stadium paling banyak diperoleh pada stadium 2 dengan kecemasan ringan, sedangkan pada stadium 3 menunjukan cemas sedang dan stadium 4 menunjukan cemas berat. pada frekuensi kemoterapi paling banyak menunjukan cemas ringan pada kemoterapi ke 5 dan cemas sedang pada kemoterapi ke 4 .

Berdasarkan analisa hubungan antara factor-faktor yang mempengaruhi kecemasan dengan tingkat kecemasan dilihat dari nilai $\mathrm{p}$ value 0.000 maka didapatkan hasil berupa stadium kanker berhubungan dengan tingkat kecemasan.

Berdasarkan hasil analisa didapatkan bahwa tingkat usia lansia paling banyak menunjukan tingkat kecemasan dibandingkan dengan usia dewasa, hal ini dimungkinkan 
karena pada usia lansia terjadi penurunan respon pikologis dimana seseorang akan mudah mengalami cemas dan depresi. Pada tingkat pekerjaan menunjukan bahwa paling banyak mengalami kecemasan dialami oleh ibu RT dan petani hal ini dimungkinkan pekerjaan Ibu RT dan petani sangat sibuk sehingga minimnya informasi terkait tindakan kemoterapi sehingga mempengaruhi kecemasan.

Berdasarkan tingkat
pendidikan didapatkan bahwa
kecemasan paling banyak didapatkan
pada tingkat pedidikan SD dan SMP
hal ini dimungkinkan karena tingkat
pendidikan SD dan SMP sangat
minim untuk mendapatkan sumber
informasi terkait pengobatan
kemoterapi.

Berdasarkan stadium kemoterapi didapatkan paling banyak mengalami kecemasan pada stadium 2 dan 3 dimana stadium tersebut pasien merasa cemas karena merasa takut akan penyakitnya yang akan menggangu kesehatan. Berdasarkan frekwensi kemoterapi didapatkan paling banyak mengalami kecemasan yaitu pada frekwensi ke 4 dan 5 hal ini dimungkin karena efek kemoterapi tersebut sangat mempengaruhi penurunan kondisi fisik/tubuh sehingga pasien mersa cemas dan hawatir.

$$
\text { Penelitian ini selajan dengan }
$$

Purwanti (2014) dimana pada responden penelitian mempunyai tingkat adaptasi yang buruk dan mempunyai kecemasan yang tinggi. adaptasi seseorang diperlukan untuk mempersiapkan kondisi fisik dan psikologis selama menjalani pengobatan.

\section{SIMPULAN DAN SARAN}

Berdasarkan tingkat kecemasan didapatkan bawha usia lansia paling banyak mengalami cemas ringan dan sedang, tingkat pendidikan didapatkan tingkat kecemasan sedang pada pendidikan SD dan SMP, pada pekerjaan didapatkan bahwa tingkat kecemasan ringan dan sesdang pada pekerjaan IRT dan Petani, pada stadium kanker didapatkan paling banyak mengalami cemas ringan dan sedang pada stadium 2 dan 3, pada frekuensi 
kemoterapi didapatkan tingkat kecemasan ringan dan sedang pada frekwensi kemoterapi 4 dan 5.

Saran dalam penelitian yaitu kepada petugas perawat khususnya yang berada di ruang kemoterapi diharapkan dapat memberikan edukasi dan tindakan keperawatan yang dapat menurunkan kecemasan yang dialami oleh pasien yang sedang menjalani program kemoterapi.

\section{DAFTAR PUSTAKA}

Hidayat, A.(2008). Pengantar Konsep Dasar Keperawatan, Jakarta : Salemba Medika

Hidayat. (2011). Buku Panduan Kebutuhan Dasar Manusia: EGC. Jakarta

Hudak \& Gallo. (2010). Keperawatan Kritis, Volume 1, Jakarta : Penerbit EGC Kedokteran

Indrawati M . (2009). Bahaya Kanker Bagi Wanita dan Pria : Pengenalan, Penanganan Bahaya Kanker. Jakarta : AV Publiser

Isaacs, A. (2012). Panduan Belajar: Keperawatan Kesehatan Jiwa dan Psikiatrik. Jakarta: EGC

Kelana. (2011). Metodologi Penelitian Keperawatan : Panduan Pelaksannaan dan Menerapkan Hasil Penelitian. Cetakan Pertama. Jakkarta.CV
Keliat, A, B. (2011). Management Kasus Gangguan Jiwa, Jakarta, ECC

Koizer. (2010). Fundamental Of Nursing. EGC.Jakarta

Kozier, Erb, Berman \& Snyder, (2011). Buku Fundamental Keperawatan Konsep, Proses dan Praktik Volume 1. Jakarta: EGC

Priambodo.G. (2015) Caring Dalam Asuhan Keperawatan, Kategori Caring Berdasarkan Budaya. Tesis

Price, S.A. \& Wilson.L.M.G (2010). Patofisiologi : Konsep Klinis Proses Penyakit Edisi 6 volume 2 Jakarta : EGC

Rasjidi, I (2012). Kemoterapi Kanker Ginekologi dalam Praktek Sehari-hari. Jakarta : Sagung Seto

Lutfa, U. (2008). Faktor-Faktor Yang Mempengaruhi Kecemasan Dalam Tindakan Kemoterapi Di RS. Moewardi Surakarta.

Mardiyono. 2012. The Effects of The Nursing-Based Intervension Islamic Relaxation on Anxiety and Persived Control in Indonesian Patients with Acute Myocardial Infaction Admitted in ICCU.

Mehran. (2016). The Effectiveness of Progressive Muscle Relaxation To Reduce The Anxiety Of Patients With Gastric Cancer. http// www.jcrs010.com journal of current research in science.

Smeltzer, S.C \& Bare, B.G. (2010). Buku Ajar Keperawatan Medikal Bedah Brunner \& Suddart. Jakarta : EGC. 
Viva Medika: Jurnal Kesehatan, Kebidanan, dan Keperawatan, 11 (02), Maret 2019

Danang Tri Yudono (Analisis Faktor-Fakor Yang Mempengaruhi Kecemasan Pasien Ca Mamae Dengan Tindakan Kemoterapi )

\section{Praptini (2013) Pengaruh Tehnik}

Muskulo Progresive Terhadap

Penurunan Kecemasan Pada

Pasien Kemoterapi Di Rumah

Singgah Kanker Denpasar 